\title{
IMPLEMENTASI METODE PEMBELAJARAN KOOPERATIF TEKNIK KELILING RUANGAN (GALLERY WALK) PADA HASIL BELAJAR MATA PELAJARAN AQIDAH AKHLAK
}

\author{
Ela Fidayanti \\ MI Hidayatul Islam Mentoro \\ elafidayanto@gmail.com
}

\begin{abstract}
ABSTRAK
Upaya guru dalam mencapai tujuan belajar Aqidah Akhlak pada bab akhlak terpuji dan akhlak tercela dapat ditempuh dengan menggunakan metode kooperatif teknik keliling ruangan (Gallery walk). Fokus penelitian masalah dalam skripsi ini adalah : 1. Bagaimana implementasi metode pembelajaran kooperatif teknik keliling ruangan (Gallery Walk) pada hasil belajar mata pelajaran aqidah akhlak kelas III MI Hidayatul Islam Mentoro? 2. Apa faktor pendukung dan penghambat penggunaan metode pembelajaran kooperatif teknik keliling ruangan (Gallery Walk) pada hasil belajar mata pelajaran aqidah akhlak kelas III MI Hidayatul Islam Mentoro? Adapun tujuan: 2. Untuk mengetahui bagaimana implementasi metode pembelajaran kooperatif teknik keliling ruangan (Gallery Walk) pada hasil belajar mata pelajaran aqidah akhlak kelas III MI Hidayatul Islam Mentoro.2. Untuk mengetahui faktor pendukung dan penghambat penggunaan metode pembelajaran kooperatif teknik keliling ruangan (Gallery Walk) pada hasil belajar mata pelajaran aqidah akhlak kelas III MI Hidayatul Islam Mentoro.

Metode yang digunakan dalam penelitian ini adalah kualitatif. Dalam pengumpulan datanya menggunakan metode observasi, wawancara, dan dokumentasi serta menggunakan analisis data reduksi, penyajian data dan penarikan kesimpulan. Peneliti juga menggunakan pengecekan keabsahan data dengan menggunakan tringulasi dan member chek.

Penggunaan metode kooperatif ini menjadikan siswa mampu bersinergi dalam proses pembelajaran dikelas serta menghargai dan mengapresiasi hasil belajar teman satu kelompoknya maupun teman lain kelompok. Serta siswa kelas III ini melakukan atau mengaktifkan fisik dan mental siswa selama proses belajar dan siswa kelas III ratarata mampu menerima kritik dengan sikap positif.
\end{abstract}

Kata Kunci: Kooperatif learning, hasil belajar, aqidah akhlaq. 


\section{PENDAHULUAN}

Menurut muhibbidin, bahwa pemilihan metode mengajar atau model pembelajaran perlu memperhatikan hal-hal sebagai berikut: a. Tujuan pengajaran, b. Materi pengajaran, c. banyaknya siswa, d. kemampuan siswa, e. Kemampuan guru atau dosen. Agar siswa mampu mencapai tujuan pendidikan melalui pengajaran maka guru harus memilih metode pembelajaran yang tepat dan relevan dengan kondisi belajar siswa ${ }^{1}$.

Metode pembelajaran adalah suatu cara yang harus dilalui di dalam pembelajaran. Untuk mencapai hasil belajar yang memuaskan diperlukan suatu metode pembelajaran Aqidah Akhlak yang mampu mengaktifan siswa dalam proses mengajar. Sebagai besar metode pembelajaran yang digunakan guru adalah metode pembelajaran konvensional, disamping dengan mengunakan system ceramah, sehingga mendorong aktivitas siswa yang cenderung diam, mendengarkan dan mencatat hal yang penting dari materi belajar. Pemilihan metode yang tidak tepat inilah yang akan mengakibatkan tidak optimalnya proses pembelajaran sehingga hasil pembelajaran juga tidak akan maksimal.

Berdasarkan kenyataan tersebut, maka mengunakan metode pembelajaran kooperatif teknik keliling ruangan (gallery walk). Teknik keliling ruangan gallery walk merupakan bagian dari metode pembelajaran kooperatif yang dapat melatih siswa untuk memecahkan masalah dengan berkelompok. Di mana dalam kelompok ini masingmasing anggota kelompok menilai dan mengigat apa yang mereka pelajari dengan memberikan kontri busi mereka dan mendengarkan anggota lain.

Metode ini memiliki kelibahan siswa terbiyasa membangun kerjasama memecahkan masalah dalam belajar, terjadi sinergi saling menguatkan pemahaman terhadap tujuan pembelajaran, membiyasan siswa bersikap menghargai dan mengapresiasi hasil belajar kawan. Mengaktifkan fisik dan mental siswa selama proses belajar, dan membiyasakan siswa memberi dan menerima keritik. Di samping itu, memiliki kelemahan yaitu pengaturan seting kelas yang lebih rumit. Namun kelemahan itu biayasa ditutupi kelebihan yang diperoleh dari penerapan pembelajaran kooperatif teknik keliling ruangan (gallery walk).

\footnotetext{
${ }^{1}$ Abdullah. Inovasi Pembelajaran. (Jakarta: Bumi Aksara. 2015). Hlm. 112
} 
Mata pelajaran Aqidah Akhlak merupakan salah satu mata pelajaran yang menuntut pemahaman dan ketelitian yang tinggi dari siswa. Pengajaran Aqidah Akhlak, guru diharapkan mampu menanamkan konsep awal pada siswa. Siswapun dituntut untuk memiliki pemikiran yang kritis dan kreatif untuk bisa mamahami pelajaran Aqidah Akhlak dengan baik. Maka tidak jarang siswa tidak begitu tertarik pada mata pelajaran ini karena jika tidak memahami diawal akan merasa tertingal. Dalam proses pembelajaran Aqidah Akhlak di kelas banyak ditemukan tingkah laku siswa yang dapat mempengaruhi hasil belajar, misalnya siswa kurang memperhatikan penjelasan guru, siswa tidak mempunyai kemauan dalam mengikuti pelajaran Aqidah Akhlak, siswa kurang konsentrasi dan pasif pada pelajaran Aqidah Akhlak, anggapan siswa bahwa pmebelajaran Aqidah Akhlak.

Berdasarkan hasil pengamatan sementara yang dilakukan di MI Hidayatul Islam Mentoro khususnya dikelas III, pada mata pelajaran Aqidah Akhlak masih ditemukan pembelajaran yang cenderung belum efektif diantaranya; (1) penerapan medel-model pembelajaran belum sesuai dengan meteri belum diajarkan, sehinga siswa merasa jenuh dan bosan di dalam kelas karena guru belum sepenuhnya melibatkan siswa dalam pembelajaran. (2) minat siswa untuk mengikuti pembelajaran masih kurang. (3) kurangnya intraksi antar guru dan siswa. (4) hasil belajar siswa masih banyak yang belum mencapai ketuntasan. Hal ini disebabkan karena proses pembelajaran berlangsung guru masih menerapkan metode cerama dan belum sepenuhnya melibatkan siswa secara aktif selama proses pembelajaran, akibatnya siswa hanya pada menit-menit awal saja memperhatikan penjelasan materi dari guru, namun pada menit-menit selanjutnya siswa mulai menunjukkan rasa kebosanan mereka dengan sering keluar masuk kelas, dan bahkan bermain dengan teman sebangkunya. Sehingga ketika diakhir pelajaran guru melakukan Tanya jawab hanya ada beberapa siswa saja yang bisa menjawab pertanyaan dari guru. Jika kegiatan pemebelajaran seperti ini, maka akan berdampak pada hasil belajar.

Metode pembelajaran kooperatif teknik keliling ruangan (Gallery walk). Sangat baik untuk menanamkan pengetahuan pada siswa dalam pembelajaran Aqidah Akhlak. Metode ini dianggap tepat digunakan karena pembelajaran kooperatif teknik keliling ruangan (Gallery walk) menuntut perhatian tinggi dari siswa. Siswa dapat membuat 
kesalahan yang sama seperti yang dilakukan temannya jika siswa itu tidak memperhatikan teman-temannya yang menjawab soal pada putaran sebelumnya. Metode pembelajaran kooperatif teknik keliling ruangan (Gallery walk) secar sosial berimplikasi pada tumbuhnya sikap kooperatif.

Metode pembelajaran kooperatif teknik keliling ruangan (Gallery walk) juga menuntut guru untuk lebih kreatif dan inovatif untuk menyiapakan soal-soal yang baru. Metode ini sanagat cocok diterapakan dalam pembelajaran Aqidah Akhlak karena materi yang dipelajari dalam Aqidah Akhlak menuntut perhatian dan ketelitian yang tinggi dari siswa. Dengan menerapakan metode ini, minat belajar Aqidah Akhlak siswa akan lebih tinggi dan pemahaman mereka akan meningkat. Metode mengajar yang menyenangkan diharapkan bisa memacu semangat siswa dalam belajar dan kemudian meningkatkan hasil belajar siswa.

\section{PEMBAHASAN}

Tabel 1. Catatan Lapangan Tentang Aktivitas Siswa Sebelum Implementasi Metode Pembelajaran Kooperatif Teknik Keliling Ruangan (Gallery Walk)

\begin{tabular}{|c|c|}
\hline Kategori & Deskripsi \\
\hline $\begin{array}{l}\text { Keaktifan siswa } \\
\text { dalam mendengarkan } \\
\text { penjelasan guru }\end{array}$ & $\begin{array}{l}\text { Hanya } 13 \text { siswa yang mendengarkan penjelasan guru, } 3 \\
\text { siswa lainnya tidak menghiraukan apa yang disampaikan } \\
\text { guru }\end{array}$ \\
\hline $\begin{array}{l}\text { Keaktifan siswa } \\
\text { dalam mengajukan } \\
\text { pertanyaan }\end{array}$ & $\begin{array}{l}\text { Hanya } 7 \text { siswa yang mengajukan pertanyaan sesuai dengan } \\
\text { materi, } 4 \text { siswa pertanyaannya menyimpang dari materi, } \\
\text { dan } 5 \text { siswa lainnya tidak mengajukan pertanyaan. }\end{array}$ \\
\hline $\begin{array}{l}\text { Keaktifan } r \text { siswa } \\
\text { dalam mengerjakan } \\
\text { tugas }\end{array}$ & $\begin{array}{l}\text { Hanya } 10 \text { siswa yang mengerjakan tugas dengan mandiri, } 6 \\
\text { siswa mengerjakan tugas tetapi menyontek pakerjaan teman } \\
\text { sebangkunya, }\end{array}$ \\
\hline $\begin{array}{lr}\text { Keaktifan } & \text { siswa } \\
\text { dalam menyampaikan } \\
\text { pendapat dan } \\
\text { berbagi/sharing } \\
\text { dengan teman }\end{array}$ & $\begin{array}{l}\text { Saat kerja kelompok hanya } 10 \text { siswa yang aktif } \\
\text { menyampaikan pendapat dan berbagi/sharing pengetahuan } \\
\text { dengan temannya, } 6 \text { siswa lainnya hanya diam dan } \\
\text { mendengarkan. }\end{array}$ \\
\hline $\begin{array}{l}\text { Keaktifan siswa } \\
\text { dalam menyimpulkan } \\
\text { materi yang telah } \\
\text { dibahas }\end{array}$ & $\begin{array}{l}\text { Hanya } 13 \text { siswa yang aktif dalam menyimpulkan materi, } \\
\text { dan } 3 \text { siswa lainnya hanya diam dan mendengarkan. }\end{array}$ \\
\hline
\end{tabular}


Berdasarkan data di atas yang dilakukan oleh peneliti pada hari sabtu tanggal 23 maret 2019, diperoleh hasil observasi sebagai berikut: 1) sebagian siswa tidak mendengarkan saat guru menjelaskan materi pembelajaran, 2) hanya beberapa siswa yang aktif bertanya mengenai materi yang disampaikan oleh guru, 3) siswa tidak bertanggung jawab terhadap tugas karena malas mengerjakan dan cendrung menyalin pekerjaan teman, 4) siswa nampak kurang berpartisipasi aktif dalam menyimpulkan materi yang telah dibahas, $50 \%$ hanya beberapa siswa yang aktif menjawab pertanyaan.

Tabel 2. Setelah Dilakukan Implementasi Metode Pembelajaran Kooperatif Teknik Keliling Ruangan (Gallery Walk)

\begin{tabular}{|c|c|}
\hline Kegiatan Guru & Kegiatan Siswa \\
\hline $\begin{array}{l}\text { Kegiatan Awal } \\
\text { ( } 10 \text { Menit ) }\end{array}$ & $\begin{array}{l}\text { Kegiatan Awal } \\
\text { ( } 10 \text { Menit ) }\end{array}$ \\
\hline $\begin{array}{l}\text { a. Guru memberikan salam, } \\
\text { mempersiapkan kelas dalam pelajaran } \\
\text { b. Guru menjelaskan KD dan Indikator } \\
\text { yang akan dicapai }\end{array}$ & $\begin{array}{l}\text { a. Siswa mempersiapkan diri untuk } \\
\text { mengikuti pelajaran dengan baik } \\
\text { b. Siswa mendengarkan dengan } \\
\text { seksama }\end{array}$ \\
\hline $\begin{array}{l}\text { c. Guru menyampaikan langkah-langkah } \\
\text { pembelajaran yang akan digunakan }\end{array}$ & $\begin{array}{l}\text { c. Siswa memperhatikan penjelasan } \\
\text { guru }\end{array}$ \\
\hline $\begin{array}{l}\text { Kegiatan Inti } \\
\text { ( } 70 \text { Menit ) }\end{array}$ & $\begin{array}{l}\text { Kegiatan Inti } \\
\text { ( } 70 \text { Menit ) }\end{array}$ \\
\hline $\begin{array}{l}\text { a. Mendemonstra-sikan pengetahuan } \\
\text { dengan menyampaikan konsep akhlak } \\
\text { terpuji dan akhlak tercela, fungsi } \\
\text { akhlak terpuji dan akhlak tercela, } \\
\text { tingkatan dan keterampilan akhlak } \\
\text { terpuji dan akhlak tercela, bidang } \\
\text { akhlak terpuji dan akhlak tercela, dan } \\
\text { akhlak terpuji dan akhlak tercela dalam } \\
\text { kegiatan sekolah. }\end{array}$ & $\begin{array}{llll}\text { a. } & \begin{array}{l}\text { Memahami materi } \\
\text { disampaikan }\end{array} & \text { yang } \\
\end{array}$ \\
\hline $\begin{array}{l}\text { bengondisikan kelas untuk } \\
\text { melaksanakan diskusi }\end{array}$ & b. Membentuk kelompok diskusi \\
\hline $\begin{array}{l}\text { c. Menugaskan masing-masing kelompok } \\
\text { untuk menelaah soal yang ditempelkan } \\
\text { dimeja dan menulis jawaban di bawah } \\
\text { soal pada lembaran yang sama }\end{array}$ & $\begin{array}{l}\text { c. Masing-masing kelompok } \\
\text { berdiskusi dan menulis jawaban di } \\
\text { bawah soal }\end{array}$ \\
\hline $\begin{array}{l}\text { d. Meminta semua kelompok berpindah } \\
\text { ke meja lain yang ditempelkan soal }\end{array}$ & $\begin{array}{l}\text { d. Masing-masing } \\
\text { berpindah ke meja lain sampai }\end{array}$ \\
\hline
\end{tabular}


yang berbeda dan menambahkan jawaban yang mungkin belum dikerjakan oleh kelompok sebelumnya. Kelompok lain juga dapat memberikan koreksi atas jawaban yang telah ditulis. Perpindahan kelompok dilakukan sampai semua soal dibahas oleh semua kelompok.

e. Meminta semua kelompok membuat ringkasan untuk soal yang berbeda yang akan dilaporkan di depan kelas

f. Menugaskan semuaperwakilan kelompok untuk memaparkan ringkasan penyelesaian soal di depan kelas

\section{Kegiatan Akhir} ( 10 Menit )

a. Memberikan post test.

b. Guru menyimpulkan apa yang telah disampaikan dan Menutup pelajaran dengan do'a dan salam. semua soal dibahas oleh semua kelompok

e. Masing-masing kelompok membuat ringkasan untuk soal yang berbeda

f. Masing-masing perwakilan kelompok memaparkan ringkasan di depan kelas

\section{Kegiatan Akhir}

( 10 Menit )

a. Menjawab pertanyaan yang ada di lembar post test.

b. Siswa mendengarkan dengan baik dan mencatat dan Berdo'a bersama dan menjawab salam dari guru.

Hasil pengamatan menunjukkan bahwa aktivitas guru yang mana guru sudah mampu menarik perhatian siswa, sehingga siswa mnegalami peningkatan dalam kegiatan pembelajaran. Peneliti menangkap bahwa siswa mampu mengerjakan keseluruhan tugas dengan baik dan mandiri, karena berani bertanya dan mampu mengemukakan pendapat sehingga tidak mengalami kesulitan dalam memahami materi pelajaran.

\section{Analisis Lingkungan di MI Hidayatul Islam Mentoro}

Keberhasilan belajar dipengaruhi oleh lingkungan, merupakan salah satu faktor penunjang. Tembat dan lingkungan belajar yang nyaman memudahkan siswa untuk berkonsentrasi. Dengan mempersiapkan lingkungan yang tepat, siswa akan mendapatkan hasil yang lebih baik dan dapat menikmati proses belajar yang siswa lakukan. Selanjutnya dalam buku dasar-dasar pendidikan yang di tulis Marina Gazali: 
Lingkungan dapat diartikan sebagai segala sesuatu yang berada diluar diri anak. Dalam artinya lingkungan adalah segala sesuatu yang ada disekitar anak, baik berupa benda-benda, peristiwa-peristiwa yang terjadi maupun kondisi masyarakat terutama yang dapat memberi pengaruh kuat kepada anak didik yaitu lingkungan yang mana terjadi proses pendidikan berlangsung dan lingkungan anak-anak bergaul sehari-hari ${ }^{2}$.

Kondisi lingkungan MI Hidayatul Islam Mentoro cenderung sangat baik untuk digunakan sebagai tempat proses belajar mengajar karena lingkungan di sana bersih serta guru-guru yang mengajar di sana sangat ramah. MI Hidayatul Islam Mentoro mempunyai banyak ruangan yang digunakan sebagai beberapa ruangan yang terdiri dari 9 rungan. 6 rungan digunakan sebagai kelas, 1 rungan digunakan sebagai kantor, 1 rungan digunakan sebagai perpustakaan, dan 1 rungan digunakan sebagai kamar mandi.

\section{Implementasi Metode Pembelajaran Kooperatif Teknik Keliling Ruangan} (Gallery Walk) Pada Hasil Belajar Mata Pelajaran Aqidah Akhlak Kelas III

Berdasarkan hasil wawancara dengan guru Aqidah Akhlak di MI Hidayatul Islam Mentoro pada hari sabtu tanggal 23 Maret 2019 sebelum dilakukan proses belajar-mengajar dengan menggunakan metode kooperatif teknik keliling ruangan (gallery walk), diperoleh keterangan bahwa pelaksanaan kegiatan pembelajaran belum maksimal. Padahal guru sudah berupaya maksimal dalam mengajar, namun belum semua siswa merespon dengan aktif, sehinga guru: 1) kesulitan dalam menyampaikan materi pembelajaran dengan menerapkan metode yang inovatif karena tuntunan ketercapaian materi sementara waktu terbatas. 2) kesulitan dakam bimbingan siswa untuk memahami materi Aqidah Akhlak. 3) kesulitan dalam mengarahkan siswa pasif dalam proses pembelajaran. 4) kesulitan dalam mengajak seluruh siswa berpartisipasi aktif dalam menyimpulkan materi yang telah dibahas.

Hasil pengamatan menunjukkan bahwa aktivitas guru yang mana guru sudah mampu menarik perhatian siswa, sehingga siswa mnegalami peningkatan dalam kegiatan pembelajaran. Peneliti menangkap bahwa siswa mampu mengerjakan keseluruhan tugas dengan baik dan mandiri, karena berani bertanya dan mampu

\footnotetext{
${ }^{2}$ Marina Gazali, Dasar-Dasar Pendidikan, (Bandung: Mizan, 1998). Hlm 43
} 
mengemukakan pendapat sehingga tidak mengalami kesulitan dalam memahami materi pelajaran.

Hasil dari penelitian ini membuktikan bahwa implementasi metode pembelajaran kooperatif teknik keliling ruangan (gallery walk) berhasil digunakan dalam proses belajar-mengajar siswa kelas III MI Hidayatul Islam Mentoro dengan mata pelajaran akidah akhlak. Diperoleh hasil, siswa kelas III MI Hidayatul Islam Mentoro mendirikaan sebuah kelompok-kelompok kecil yang berangotakan laki-laki dan perempuan dengan tujuan kelompok tersebut lebih variatif dalam proses belajarmengajar di dalam kelas. Hal ini membuktikan bahwa mereka mampu menerapkan metode pembelajaran kooperatif dengan membuat kelompok-kelompok kecil dengan anggota yang heterogen.

Siswa dalam kelompok yang dibentuk tersebut melakukan tugasnya masingmasing atau melakukan pembagian tugas agar kelompok yang dibentuk lebih efektif dalam proses belajar-mengajar. Teknik keliling kelompok merupakan teknik pembelajaran dimana masing-masing anggota kelompok mendapatkan kesempatan memberikan kontribusi mereka dan mendengarkan pandangan pemikiran anggota yang lain ${ }^{3}$.

3. Faktor Pendukung dan Penghambat Penggunaan Metode kooperatif teknik keliling ruangan (gallery walk) pada hasil belajar mata pelajaran aqidah akhlak kelas III

Kelebihan teknik keliling ruangan (gallery walk) di antaranya adalah:

a. Siswa terbiasa membangun budaya kerjasama memecahkan masalah dalam belajar;

b. Terjadi sinergi saling mengunakan pemahaman terhadap tujuan pembelajaran;

c. Memberikan siswa bersikap menghargai dan mengapresiasi hasil belajar kawannya;

d. Mengaktifkan fisik dan mental siswa selama proses belajar;

\footnotetext{
${ }^{3}$ Isjoni. Cooperative Learning Ektifitas Pembelajaran Berkelompok. (Bandung:
} Alfabeta 2011). Hlm 43 
e. Membiasakan siswa memberi dan menerima kritik ${ }^{4}$

Kelebihan penggunaan teknik keliling ruangan (gallery walk) yang dilakukan siswa MI Hidayatul Islam Mentoro dalam melakukan proses belajar-mengajar mampu melakukan kerjasama memecahkan masalah dalam proses belajar. Hal ini terbukti dalam pembuatan kelompok yang dilakukan guru dikelas, mereka membegi tugas dalam berkelompok. Selanjutnya, menjadikan siswa mampu bersinergi dalam proses pembelajaran dikelas serta menghargai dan mengapresiasi hasil belajar teman satu kelompoknya maupun teman lain kelompok. Serta siswa kelas III ini melakukan atau mengaktifkan fisik dan mental siswa selama proses belajar dan siswa kelas III rata-rata mampu menerima kritik dengan sikap positif.

Kelemahan teknik keliling ruangan (gallery walk) diantaranya adalah:

a. Bila anggota terlalu banyak akan terjadi sebagaian siswa menggantungkan kerja kawannya;

b. Guru perlu ekstra cermat dalam memantau dan menilai keaktifan individu dan kolektif;

c. Pengaturan seting kelas yang lebih rumit $^{5}$;

Kelemahan proses ini dalam kelas III MI Hidayatul Islam Mentoro adalah dengan dibentuknya kelompok-kelompok dalam proses belajar-mengajar menjadikan beberapa siswa yang malas menjadi menggantungkan tugas mereka pada teman satu kelompoknya. Oleh sebab itu guru yang mengajar kadang dituntut ekstra cermat dalam memantau dan menilai keaktifan individu. Dengan adanya metode ini, guru kelas III juga menjadi ekstra dalam bekerja karena harus menyeting kelas dengan rumit.

\footnotetext{
${ }^{4}$ Nasution. Berdasarkan Pendidikan Dalam Proses Belajar dan Mengajar. (Jakarta: Bumi Aksara 2003). Hlm 34

5 Nasution. Berbagai Pendidikan dalam Proses Belajar dan Mengajar. (Jakarta: Bumi Aksara 2003). Hlm 23
} 


\section{KESIMPULAN}

Berdasarkan hasil analisis data dan pembahasan hasil penelitian mengenai pembelajaran kooperatif teknik keliling ruangan (gallery walk) diperoleh kesimpulan bahwa implementasi metode pembelajaran kooperatif teknik keliling ruangan (gallery walk) berhasil digunakan dalam proses belajar-mengajar siswa kelas III MI Hidayatul Islam Mentoro dengan mata pelajaran akidah akhlak.

Tentu dalam teknik ini pasti ada kelebihan dan kekurangan dalam proses pengaplikasiannnya, kelebihan penggunaan teknik keliling ruangan (gallery walk) yang dilakukan siswa MI Hidayatul Islam Mentoro dalam melakukan proses belajar-mengajar mampu melakukan kerjasama memecahkan masalah dalam proses belajar. Hal ini terbukti dalam pembuatan kelompok yang dilakukan guru di kelas, mereka membagi tugas dalam berkelompok. Selanjutnya, menjadikan siswa mampu bersinergi dalam proses pembelajaran dikelas serta menghargai dan mengapresiasi hasil belajar teman satu kelompoknya maupun teman lain kelompok. Serta siswa kelas III ini melakukan atau mengaktifkan fisik dan mental siswa selama proses belajar dan siswa kelas III ratarata mampu menerima kritik dengan sikap positif.

Sedangkan kelemahan proses ini dalam kelas III MI Hidayatul Islam Mentoro adalah dengan dibentuknya kelompok-kelompok dalam proses belajar-mengajar menjadikan beberapa siswa yang malas menjadi menggantungkan tugas mereka pada teman satu kelompoknya. Oleh sebab itu guru yang mengajar kadang dituntut ekstra cermat dalam memantau dan menilai keaktifan individu. Dengan adanya metode ini, guru kelas III juga menjadi ekstra dalam bekerja karena harus mengatur kelas dengan rumit.

\section{DAFTAR PUSTAKA}

Abdullah. 2015. Inovasi Pembelajaran. Jakarta: Bumi Aksara. Marina Gazali, 1998. Dasar-Dasar Pendidikan, Bandung: Mizan.. Isjoni. 2011. Cooperative Learning Ektifitas Pembelajaran Berkelompok. Bandung: Alfabeta.

Nasution. 2003. Berbagai Pendidikan dalam Proses Belajar dan Mengajar. (Jakarta: Bumi Aksara. 